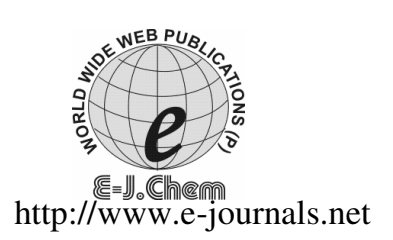

ISSN: 0973-4945; CODEN ECJHAO

E-Journal of Chemistry

2011, 8(3), 1212-1217

\title{
Simultaneous Estimation of Gemcitabine Hydrochloride and Capecitabine Hydrochloride in Combined Tablet Dosage Form by RP-HPLC Method
}

\author{
V.RAJESH, B.ANUPAMA ${ }^{\S *}$, V.JAGATHI ${ }^{\S}$ and P.SAI PRAVEEN ${ }^{\S}$ \\ M.I.C College of Technology, Vijayawada-521180, A.P, India \\ ${ }^{\S}$ K.V.S.R.Siddhartha College of Pharmaceutical Sciences \\ Siddhartha Nagar, Vijayawada - 520 010, A.P., India \\ valluru70787@gmail.com
}

Received 26 September 2010; Accepted 27 November 2010

\begin{abstract}
A new reverse phase high performance liquid chromatography (RP-HPLC) method has been developed for the simultaneous estimation of gemcitabine hydrochloride and capecitabine hydrochloride in combined tablet dosage form. An inertsil ODS-3 C-18 column having dimensions of $250 \times 4.6 \mathrm{~mm}$ and particle size of $5 \mu \mathrm{m}$, with mobile phase containing a mixture of acetonitrile : water : triethyelamine in the ratio of $(70: 28: 2 \mathrm{v} / \mathrm{v})$ was used. The $\mathrm{pH}$ of mobile phase was adjusted to 4.0 with ortho-phosphoric acid. The flow rate was $1 \mathrm{~mL} / \mathrm{min}$ and the column effluents were monitored at $260 \mathrm{~nm}$. The retention time for gemcitabine hydrochloride and capecitabine hydrochloride was found to be 2.76 and 2.3 min respectively. The proposed method was validated in terms of linearity, accuracy, precision, limit of detection, limit of quantitation and robustness. The method was found to be linear in the range of $10-50 \mu \mathrm{g} / \mathrm{mL}$ and $4-24 \mu \mathrm{g} / \mathrm{mL}$ for gemcitabine hydrochloride and capecitabine hydrochloride, with regression coefficient $\mathrm{r}=0.999$ and $\mathrm{r}=0.999$, respectively.
\end{abstract}

Keywords: Gemcitabine hydrochloride, Capecitabine hydrochloride, RP-HPLC

\section{Introduction}

Gemcitabine hydrochloride (GTHC) is chemically a $2^{\prime}$-deoxy-2',2'-difluorocytidine monohydrochloride is a nucleoside metabolic inhibitor that exhibits antitumor activity. Spectroscopic ${ }^{1-3}$, HPTLC $^{5-6}$ and RP-HPLC method have been reported for the estimation of gemcitabine individually and in combination with other drugs.

Capecitabine hydrochloride (CTHC); pentyl [1-(3,4-dihydroxy-5-methyl-oxolan-2-yl)-5fluoro-2-oxo-pyrimidin-4-yl]aminoformate is given for cancer treatment for metastatic ${ }^{7}$ breast 
cancer and colorectal ${ }^{8}$ cancer, as well as adjuvant therapy for stage III. Various methods such as LC-MS ${ }^{9}$, RP-HPLC ${ }^{10,11}$ and spectrophotometric method have been reported for the estimation of capecitabine hydrochloride.

Literature survey reveals that no method has been reported so far for the estimation of these two drugs simultaneously in combined dosage forms. Hence, in the present study, a new reverse phase high performance liquid chromatography method was developed and validated for the simultaneous estimation of GTHC and CTHC in combined dosage forms.<smiles>Nc1ccn2c(=O)n(F)c(F)c(O)c(CO)cn2c1</smiles>

Figure 1. Gemcitabine hydrochloride<smiles>CCCCCOC(=O)Nc1nc(=O)n(C2OC(C)[C@@H](O)[C@H]2O)cc1F</smiles>

Figure 2. Capecitabine hydrochloride

\section{Experimental}

The GTHC and CTHC were obtained as gift samples from Swarup Exim (India), Nagpur, Maharashtra. Acetonitrile (HPLC grade), water (HPLC grade), triethylamine and orthophosphoric acid were of AR grade. The market formulation of this combination (Label claim: $200 \mathrm{mg}$ ), gemget \& capget (Getwell Life Sciences India Pvt. Ltd.) was purchased from the local market.

\section{Instrumentation}

A Water HPLC 2695 separation module with Water 2996-Photodiode array detector and Inertsil ODS-3 C-18 column having dimensions of $250 \times 4.6 \mathrm{~mm}$ and particle size of $5 \mu \mathrm{m}$ was used.

\section{Chromatographic condition}

The mobile phase containing acetonitrile: water: triethylamine $(70: 28: 2 \mathrm{v} / \mathrm{v})$ with $\mathrm{pH} 4.0$ adjusted by using orthophosphoric acid was selected as the optimum composition of mobile phase, because it was found that this solvent system resolved both the components ideally. The flow rate was set to $1 \mathrm{~mL} / \mathrm{min}$ and UV detection was carried out at $260 \mathrm{~nm}$. The mobile phase and samples were degassed by ultrasonication for $20 \mathrm{~min}$ and filtered through $0.45 \mu \mathrm{m}$ nylon 66 (N66) membrane filter paper. All determinations were performed at constant column temperature $\left(25^{\circ} \mathrm{C}\right)$.

\section{Preparation of stock solutions}

$10 \mathrm{mg}$ of standard gemcitabine hydrochloride and $10 \mathrm{mg}$ capecitabine hydrochloride were weighed accurately and transferred to two separate $100 \mathrm{~mL}$ volumetric flasks. Both the drugs were dissolved in $50 \mathrm{~mL}$ of mobile phase with shaking and then volume was made up to the mark with mobile phase to get standard stock solution of each drug. These stock solutions were filtered through $0.2 \mu \mathrm{m}$ nylon 66 (N66) membrane filter paper and having concentration of gemcitabine hydrochloride as $100 \mu \mathrm{g} / \mathrm{mL}$ and as $100 \mu \mathrm{g} / \mathrm{mL}$ capecitabine hydrochloride. 


\section{Calibration curve}

For each drug, appropriate aliquots were pipetted out from each standard stock solution into a series of $10 \mathrm{~mL}$ volumetric flasks. The volume was made up to the mark with mobile phase to obtain concentrations of 10, 20, 30, 40 and $50 \mu \mathrm{g} / \mathrm{mL}$ of GTHC and 4, 8, 12, 16, 20 and $24 \mu \mathrm{g} / \mathrm{mL}$ of CTHC. The solutions were injected in triplicates for each concentration using a $20 \mu \mathrm{L}$ loop system and chromatographed under the conditions as described earlier. Peak areas were recorded for all the peaks at $260 \mathrm{~nm}$ and a standard calibration curve of peak area against concentration was plotted.

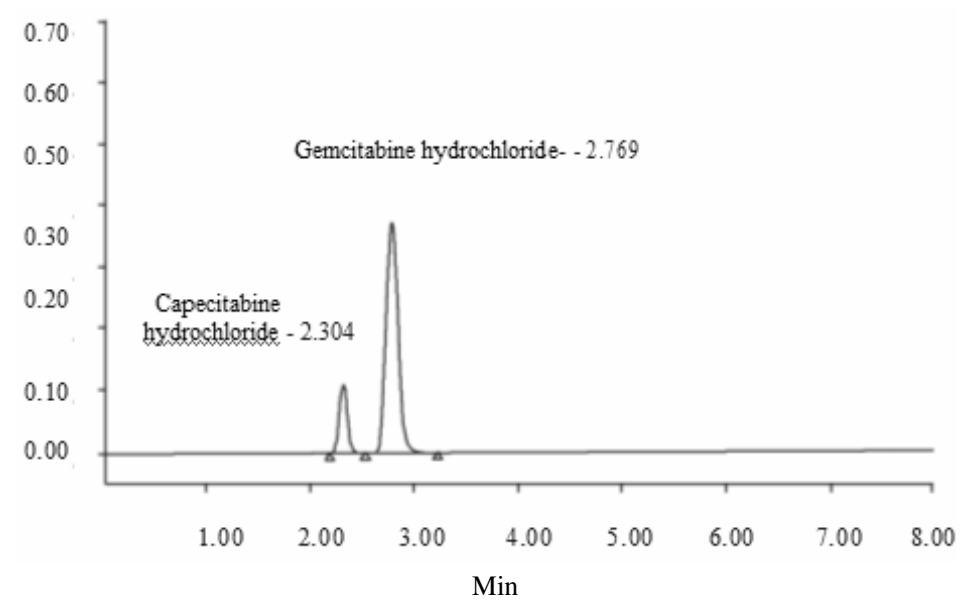

Figure 3. RP-HPLC chromatogram of a mixture of gemcitabine hydrochloride- $(40 \mu \mathrm{g} / \mathrm{mL})$ hydrochloride and capecitabine hydrochloride $(20 \mu \mathrm{g} / \mathrm{mL})$ analysis of tablet formulation

Twenty tablets were weighed and their average weight was determined and these were finely powdered. The powder equivalent to $5 \mathrm{mg}$ of GTHC and $2 \mathrm{mg}$ of CTHC was accurately weighed and transferred to $50 \mathrm{~mL}$ volumetric flask and dissolved in $25 \mathrm{~mL}$ mobile phase as diluent and the flask was kept in ultrasonicator for $10 \mathrm{~min}$. The flask was shaken and volume was made up to the mark with mobile phase. The solution was filtered through Whatman filter paper No. 41 and it contains final concentration of $100 \mu \mathrm{g} / \mathrm{mL}$ of GTHC and $40 \mu \mathrm{g} / \mathrm{mL}$ of CTHC. A $20 \mu \mathrm{L}$ volume of sample mixture was injected into the sample injector of HPLC system for six times and their chromatograms were recorded under the same chromatographic conditions as described above.

\section{Validation method}

\section{Linearity}

The standard curve was obtained in the concentration range of $10-50 \mu \mathrm{g} / \mathrm{mL}$ for gemcitabine hydrochloride and $4-24 \mu \mathrm{g} / \mathrm{mL}$ for capecitabine hydrochloride. The linearity of these methods were evaluated by linear regression analysis, using least squares method.

\section{Precision}

\section{Procedure for determination of intra-day precision}

In intra-day precision, the sample mixture containing $30 \mu \mathrm{g} / \mathrm{mL}$ of gemcitabine hydrochloride and $16 \mu \mathrm{g} / \mathrm{mL}$ of capecitabine hydrochloride was analyzed six times at different time intervals on the same day. 


\section{Procedure for determination of inter-day precision}

In inter-day precision, a set of six sample mixtures containing $30 \mu \mathrm{g} / \mathrm{mL}$ of gemcitabine hydrochloride and $16 \mu \mathrm{g} / \mathrm{mL}$ of capecitabine hydrochloride were prepared and analyzed at same time on different days. The variation of the results on different days was analyzed and statistically validated.

\section{Accuracy}

Recovery studies were carried out by applying the method to drug sample present in tablet dosage form to which known amount of gemcitabine hydrochloride and capecitabine hydrochloride corresponding to $80 \%, 100 \%$ and $120 \%$ of label claim was added (standard addition method). After the addition of the standards, the contents were transferred to $100 \mathrm{~mL}$ volumetric flask and dissolved in $50 \mathrm{~mL}$ mobile phase and the content was kept in ultrasonicator for $25 \mathrm{~min}$. Finally the volume was made up to the mark with mobile phase. The solution was filtered through Whatman filter paper No. 41. The mixed sample solutions were analyzed.

\section{Results and Discussion}

The proposed chromatographic conditions were found to be satisfactory for the determination of GTHC and CTHC in combined dosage form. The results of the assay of the marketed formulation are presented in Table 1 . The method was validated statistically and validation parameters are summarized.

Table 1. Assay results of gemcitabine hydrochloride and capecitabine hydrochloride in combined dosage form

\begin{tabular}{cccc}
\hline Drug & Label claim & \% Drug found \pm SD $^{*}$ & RSD, $\%^{*}$ \\
\hline $\begin{array}{c}\text { Gemcitabine } \\
\text { hydrochloride } \\
\begin{array}{c}\text { Capecitabine } \\
\text { hydrochloride }\end{array}\end{array}$ & $200 \mathrm{mg}$ & $98.69 \pm 0.41$ & 0.46 \\
\hline
\end{tabular}

${ }^{*}{ }_{n}=6$, SD; Standard deviation, RSD; Relative standard deviation

\section{Method validation}

The developed analytical method was subjected to validation as per the ICH guidelines.

\section{Specificity}

The specificity of the RP-HPLC method was determined by comparison of the chromatogram of standard solutions and sample solutions. The retention time of standard GTHC and CTHC were compared with that of sample solution. Good correlation was obtained between the retention time of standard and sample of GTHC and CTHC.

\section{Linearity}

Linearity was established by least square regression analysis of the calibration curve. The linearity range for the GTHC and CTHC were found to be $10-50 \mu \mathrm{g} / \mathrm{mL}$ and $4-24 \mu \mathrm{g} / \mathrm{mL}$, respectively. Peak areas of GTHC and CTHC were plotted against their respective concentrations and linear regression analysis was performed on the resultant curves. The regression equations were found to be: $y=26960 x+13795(r=0.999)$ for GTHC and $y=13786 x-1072(r=0.999)$ for CTHC, respectively. 


\section{Limit of detection (LOD) and limit of quantitation (LOQ)}

LOD and LOQ were determined based on the standard deviation of response and slope of calibration curve. LOD and LOQ were found to be 0.0018 and 0.0056 for GTHC and 0.0046 and 0.014 for CTHC, respectively.

\section{Precision}

For intra-day studies, five concentrations were injected into the HPLC system three times on the same day and for inter-day studies, five concentrations were injected into the HPLC system for three days. The data showed that RSD was found to be less than $2 \%$ for both; intra-day and inter-day studies, which shows that method is precise (Table 2).

Table 2. Intra-day and inter-day precision of the method

\begin{tabular}{cccccc}
\hline Drug & $\begin{array}{c}\text { Concentration } \\
\text { added, } \mu \mathrm{g} \mathrm{mL} \mathrm{m}^{-1}\end{array}$ & $\begin{array}{c}\text { Intra-day precision } \\
\text { Mean amount } \\
\text { foug mL } \\
(\mathrm{n}=6)\end{array}$ & $\begin{array}{c}\text { \% RSD } \\
(\mathrm{n}=6)\end{array}$ & $\begin{array}{c}\text { Inter-day precision } \\
\text { found, } \mu \mathrm{g} \mathrm{mL}^{-1} \\
(\mathrm{n}=3)\end{array}$ & $\begin{array}{c}\% \mathrm{RSD} \\
(\mathrm{n}=3)\end{array}$ \\
\hline $\begin{array}{c}\text { Gemcitabine } \\
\text { hydrochloride } \\
\text { Capecitabine } \\
\text { hydrochloride }\end{array}$ & 30 & $29.56 \pm 0.63$ & 0.46 & $29.81 \pm 0.27$ & 0.82 \\
\hline
\end{tabular}

\section{Accuracy}

Recovery studies were performed to determine the accuracy of the method. Recovery experiments were performed at three levels, in which the preanalyzed sample solutions were spiked with gemcitabine hydrochloride and capecitabine hydrochloride at $80 \%, 100 \%$ and $120 \%$ of the label claim. Three replicate samples of each concentration levels were prepared and the percentage recovery at each level was determined (Table 3).

Table 3. Accuracy studies

\begin{tabular}{|c|c|c|c|c|c|c|c|c|}
\hline \multirow{2}{*}{$\begin{array}{ll}\frac{1}{0} & \overrightarrow{0} \\
0 & 0 \\
0 & 0 \\
1 & 0 \\
0 & 0 \\
0 & 0\end{array}$} & \multicolumn{2}{|c|}{$\begin{array}{c}\text { Amount } \\
\text { present, } \mu \mathrm{g} / \mathrm{mL}\end{array}$} & \multicolumn{2}{|c|}{$\begin{array}{c}\text { Amount of } \\
\text { standard drug } \\
\text { added, } \mu \mathrm{g} / \mathrm{mL}\end{array}$} & \multicolumn{2}{|c|}{$\begin{array}{c}\text { Mean } \pm \text { S.D } \\
\text { Amount recovered }(\mathrm{mg}) \\
(\mathrm{N}=3)\end{array}$} & \multicolumn{2}{|c|}{$\begin{array}{c}\text { Mean } \pm \text { S.D } \\
\% \text { of Recovery }\end{array}$} \\
\hline & GTHC & CTHC & GTHC & СТHC & GTHC & CTHC & GTHC & CTHC \\
\hline 80 & 10 & 4 & 10 & 4 & $19.45 \pm 0.21$ & $7.76 \pm 0.37$ & $100 \pm 0.23$ & $98.58 \pm 0.2$ \\
\hline 100 & 10 & 4 & 20 & 8 & $30.07 \pm 0.54$ & $11.86 \pm 0.21$ & $100.17 \pm 05$ & $98.82 \pm 0.3$ \\
\hline 120 & 10 & 4 & 30 & 12 & $39.84 \pm 0.84$ & $15.76 \pm 0.58$ & $99.05 \pm 0.4$ & $98.74 \pm 0.6$ \\
\hline
\end{tabular}

\section{Robustness}

The robustness study was done by making small changes in the optimized method parameters like \pm 0.1 change in mobile phase composition, \pm 0.1 change in flow rate and \pm 0.1 change in column temperature. There was no significant impact on the retention time. The system suitability parameters were given in Table 4.

Table 4. Summary of system suitability parameters of gemcitabine hydrochloride and capecitabine hydrochloride

\begin{tabular}{ccc}
\hline Parameters & Gemcitabine hydrochloride & Capecitabine hydrochloride \\
\hline Retention time & 2.304 & 2.769 \\
Resolution factor & - & 2.7 \\
Tailing factor & 1.3 & 1.1 \\
Theoretical plate & 4000 & 3009 \\
\hline
\end{tabular}




\section{Conclusion}

The developed RP-HPLC method can be used for routine analysis as a method for the simultaneous estimation of gemcitabine hydrochloride and capecitabine hydrochloride in pharmaceutical dosage form. The method was validated and found to be simple, accurate and precise. Statistical analysis of the developed method has been carried out, which shows good accuracy and precision.

\section{Acknowledgment}

The authors are thankful to K.V.S.R.Siddhartha College of Pharmaceutical Sciences for providing the necessary facilities and Swarup Exim (India), Nagpur, Maharashtra for providing gift samples of Gemcitabine hydrochloride and Capecitabine hydrochloride.

\section{References}

1. Budawari S, (Ed)., in; The Merck Index, $13^{\text {th }}$ Edn., Merck \& Co., Inc., Whitehouse Station, NJ, 2001, 221.

2. Joel G H, Lee E L, Perry B M, Raymond W R and Alfred G G, (Ed.), Goodman Gilman's The Pharmacological Basis of Therapeutics. $9^{\text {th }}$ Eds., New Jersy, McGraw Hill, 1996,108.

3. Sweetman S C, Martindale: The Complete Drug Reference, $33^{\text {rd }}$ Edn., Pharmaceutical Press, London, $2002,205$.

4. http://www.drugbank.ca/drugs/DB00376

5. Saudagar R B, Swarnlata S and Saraf S, Indian J Pharm Sci., 2007, 69, 149-152.

6. $\quad$ Sejal P K and Patel N J, Indian J Pharm Sci., 2009, 71(5), 545-547.

7. http://www.drugbank.ca/drugs/DB00831

8. Capka V, Xu Y and Chen Y H, J Pharma Biomed Anal., 1999, 21(3), 507-517.

9. Miller J C and Miller J N, Statistics for Analytical Chemistry, $2^{\text {nd }}$ Edition, Chichester, UK: Ellis Horwood, 1992, 127- 129.

10. Demuth J E, Basic Statistics and Pharmaceutical Statistical Applications, Newyork, Marcel Dekker, 1999, 501- 512.

11. James Swarbrick and James C Boylan, Encyclopedia of Pharmaceutical Technology, New York: Marcel Dekker; 1988, 217-224. 


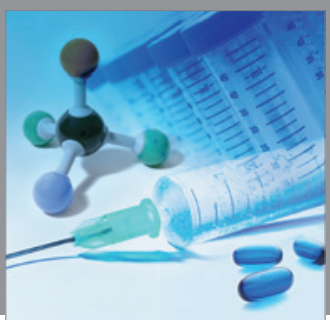

International Journal of

Medicinal Chemistry

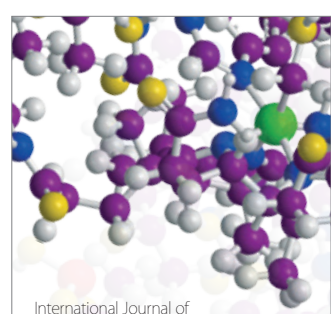

Carbohydrate Chemistry

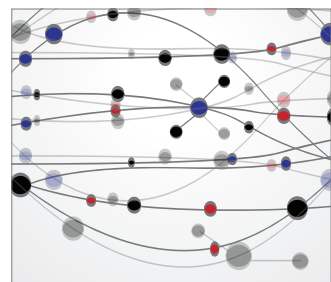

The Scientific World Journal
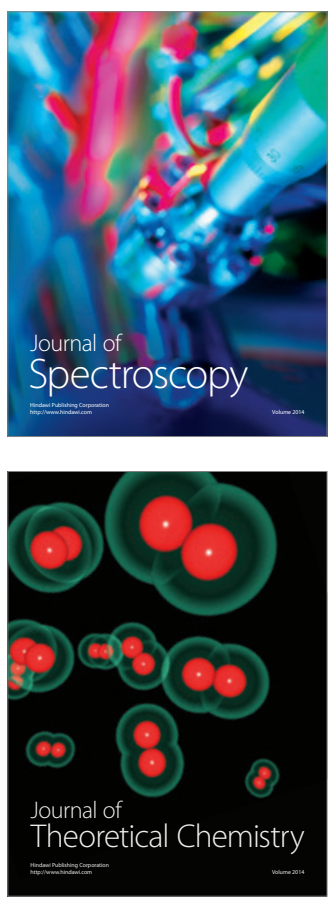
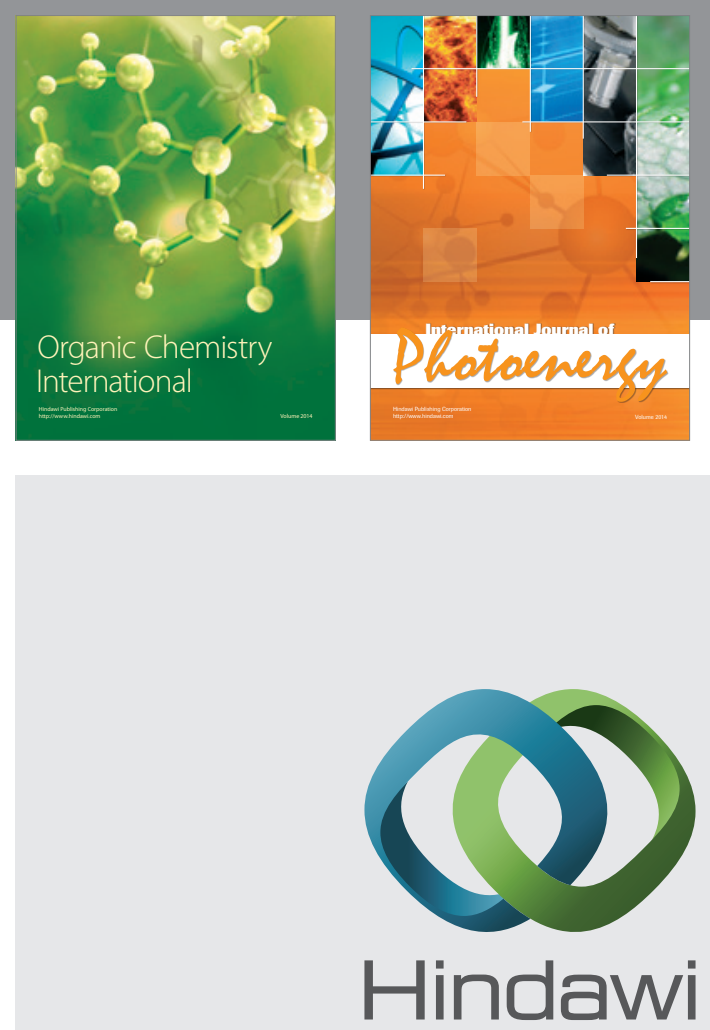

Submit your manuscripts at

http://www.hindawi.com
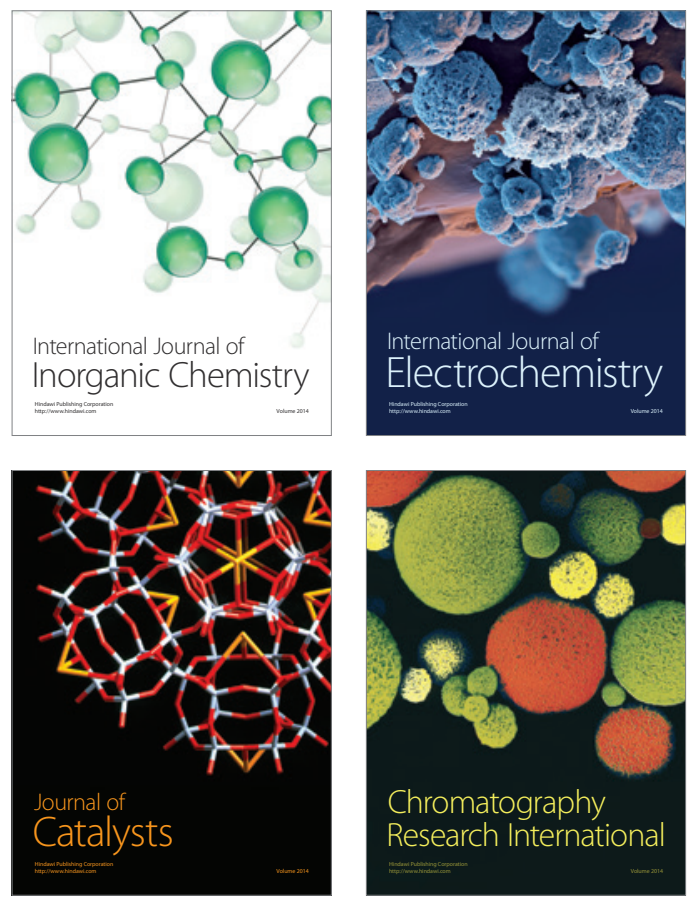
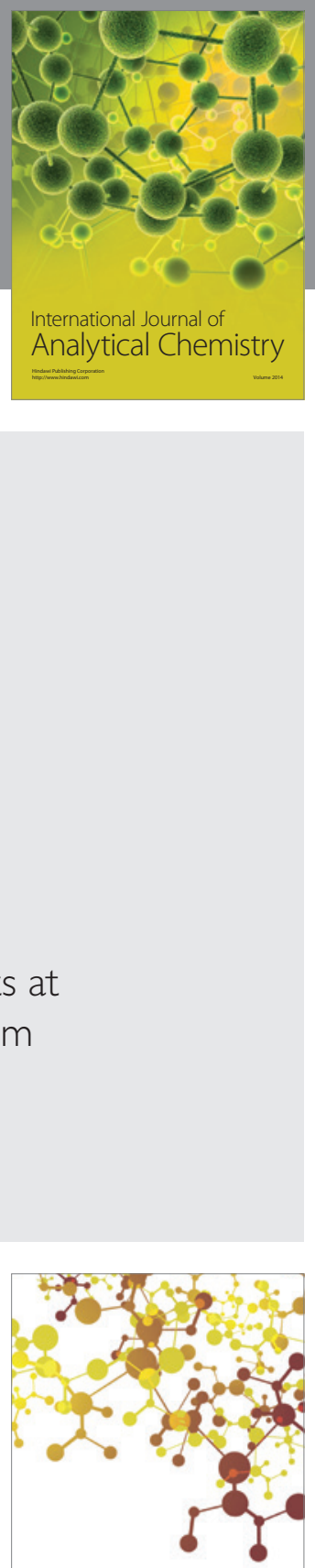

Journal of

Applied Chemistry
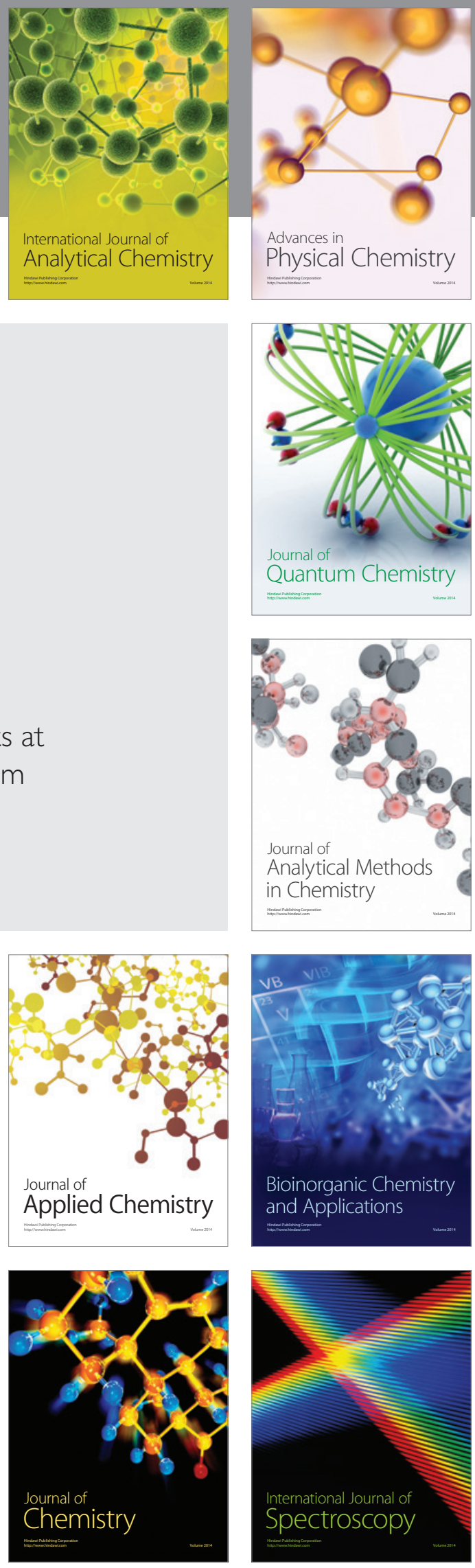